\title{
WOMEN EMPOWERMENT THROUGH MICRO FINANCE (A CASE STUDY OF N.G.O. IN PRAKASAM DISTRICT OF ANDHRA PRADESH)
}

\begin{tabular}{|c|c|}
\hline Totakura Grace ${ }^{1}$ & $\begin{array}{c}{ }^{1} \text { Research Scholar, Dept. of Rural Development, } \\
\text { Acharya Nagarjuna University, Nagarjunanagar, } \\
\text { Guntur dist. Andhra Pradesh state, India. }\end{array}$ \\
\hline Dr. V. Divya Thejomurthy 2 & $\begin{array}{c}{ }^{2} \text { Associate Professor, Dept. of Rural Development, } \\
\text { Acharya Nagarjuna University, Nagarjunanagar, } \\
\text { Guntur dist. Andhra Pradesh state, India. }\end{array}$ \\
\hline
\end{tabular}

\section{ABSTRACT}

Article DOI URL: https://doi.org/10.36713/epra5548

The present paper refers to women empowerment through Micro finance (A case study of N.G.O. in Prakasam district of Andhra Pradesh state. The main objective of this paper is to portray the profile of voluntary organization under study area. Micro finance and also SHGs are successful in reducing poverty, empowering women and providing awareness which results in development which is sustainable to the nation and also the next generation. Women have been the most deprived and discriminated strata of society not only in our country but all over the world. In spite of all the efforts of Government and Non-Government organizations they have fallen prey to the financial sector and offer themselves to surrender. The origin of the women empowerment movement could be traced back to the nineteenth century during the harsh conditions in which women had to work in and the substantially lower wages they earned in comparison to men. Further, the issues of anti-slavery, restraint, and women's suffrage, combined with the exploitation of women and children in the Industrial Revolution era further raised the movement. More than 90 per cent women respondents are married who are in need of microfinance and empowerment, so that they can support their families economically through running various small sector units or businesses. The present study can be inferred that nearly 80 per cent of the respondents are in the productive age-group of between (30-40years). This group of people can withhold courage, innovation, creativity and ability to take risk. There is a need to encourage more number of middle aged as well as above 50 years age group women also to form SHGs in order to achieve the objectives of the SHGs.

KEY WORDS: Non-Governmental Organization (NGO), Women Empowerment, Self-Help Groups, Micro Financing, Suffrage. 


\section{INTRODUCTION}

Micro finance and also SHGs are successful in reducing poverty, empowering women and providing awareness which results in sustainable development to the nation. Women have been the most deprived and discriminated strata of society not only in our country but all over the world. In spite of all the efforts of Government and Non-Government, they have fallen prey to the financial sector and offer themselves to surrender.

Initially, microfinance has been evolving to be a powerful tool for women empowerment, specifically, the rural women and their socioeconomic empowerment. The formal and semi formal sectors like commercial banks, Non-Government Organizations etc. are taking considerable emphasis as it is proven to be a profitable commercial activity in providing microfinance to women.

In availing the services women are also participating in the microfinance movement by which are being sculpted by various financial channels. Microfinance is to enable empowerment to women. Microfinance is the provision of financial services to economically backward people for those who are difficult to reach, either directly through banks or other institutions. There is a considerable lack towards the banking and other services which include consumers and self employed. The unbankables, bringing credit, savings and other essential financial services are provided by microfinance which is reachable to millions of people who are extremely poor and those who are to be served by banks because of their financial status. This in turn gives them confidence, scope to improve their status and makes them more energetic in decision making, thus leading to gender equality.

\section{Definition of Microfinance}

The definition of the Microfinance could be defined as a broad range of financial services viz., deposits, loans, money transfers and insurance to the poor people or low income households and microenterprises. In 1999, one of the teams working on micro finance set up by National Bank for Agriculture and Rural Development (NABARD) came up with a definition which has become the definitive one. In order not to equate micro-finance merely as credit for micro-enterprises which includes savings, consumption loans, housing loans and insurance services. This is a condition of thrift, credit, and other financial services and products of very little amounts to the low level of income households in rural areas, semi-urban or urban areas for facilitating them to elevate their income levels and improving their living standards". The term "micro credit" generally refers to little loans provided to low of income householders and enterprises owned by them. In the developing countries, this term has been regularly substituted by these institutions which are very much wider and refers for improving to the diversity of services that even the rural people.

\section{Women Empowerment in India}

The origin of the women empowerment movement could be traced back to the nineteenth century during the harsh conditions in which women had to work in and the substantially lower wages they earned in comparison to men. Further the issues of anti-slavery, restraint, and women's suffrage, combined with the exploitation of women and children in the Industrial Revolution era further raised the movement. This movement has also produced a dynamic set of women leaders in Europe and North America in the late nineteenth century and at the turn of the $20^{\text {th }}$ century and this has led to the establishment of the "protective" laws by the governments in a number of industrialized countries. By the 1970 s, more and more evidence with regard to the subordinate status and position of women started coming in and women's issues were vociferously raised by women's movements all over the world. Since then, the women's movements have increasingly sought to influence state policy with a view to include women issues and perspectives in the developmental agenda.

\section{Progress of saving linked SHGs with Banks (2015-16 T0 2016-17)}

The banks have reported addition of 12.70 lakh savings linked SHGs at all India level registering a growth of 14.05 percent during the year 2016-17. Among the different regions, Western Region registered the highest growth of 26.55 percent followed by Eastern Region (24.06 percent), Central Region (17.08 percent), Northern Region (14.06 percent) and North Eastern Region (7.08 percent). The lowest growth of 5.01 percent was registered in the Southern Region. Among the states, Rajasthan, Assam, Bihar, Orissa, West Bengal, Chattisgarh, Uttar Pradesh, Maharashtra, Kerala, Karnataka and Telangana registered a good growth of SHGs while states like Andhra Pradesh, Puducherry, Tripura, Arunachal Pradesh, Nagaland, Sikkim registered a negative growth of SHGs leading to decline in absolute number of SHGs in such states over the year 2015-16. The decline in savings accounts of SHGs is mainly due to data sanitization, closure of dormant accounts, under reporting for certain states, and change in the SHG Bank Linkage model for example like SHGs have shifted to linkage through Banking Correspondents.

As regards, the regional share of SHGs during the year 2016-17, Southern Region accounted for major share of 38.03 per cent, followed by Eastern Region (26.05 per cent), Western Region (13.09 per cent), Central Region (10.06 per cent) and Northern Region (5.05 per cent). The North Eastern Region had the lowest share of $5.02 \%$ of total SHGs in the country. The share of Southern Region in terms of number of SHGs declined to $38.03 \%$ in $2016-17$ from almost half (48.03\%) in 2014-15. 
Table No.1 : Region-Wise Progress of Saving Linked SHGs with Banks (2014-15 To 2016-17)

\begin{tabular}{|c|l|c|c|c|c|c|c|}
\hline \multirow{2}{*}{$\begin{array}{c}\text { Sl. } \\
\text { No. }\end{array}$} & \multicolumn{1}{|c|}{ Region } & \multicolumn{2}{|c|}{$\mathbf{2 0 1 4 - 1 5}$} & \multicolumn{2}{c|}{$\mathbf{2 0 1 5 - 1 6}$} & \multicolumn{2}{c|}{ 2016-17 } \\
\cline { 2 - 8 } & $\begin{array}{r}\text { No. of } \\
\text { SHGs }\end{array}$ & $\begin{array}{c}\text { Savings - } \\
\text { Amount }\end{array}$ & $\begin{array}{c}\text { No. of } \\
\text { SHGs }\end{array}$ & $\begin{array}{c}\text { Savings - } \\
\text { Amount }\end{array}$ & $\begin{array}{c}\text { No. of } \\
\text { SHGs }\end{array}$ & $\begin{array}{c}\text { Savings - } \\
\text { Amount }\end{array}$ \\
\hline 1 & Northern Region & 457199 & 49676.28 & 478883 & 49293.91 & 548624 & 62452.83 \\
\hline 2 & $\begin{array}{l}\text { North Eastern } \\
\text { Region }\end{array}$ & 452887 & 22955.70 & 485591 & 32207.59 & 523469 & 40407.05 \\
\hline 3 & Eastern Region & 1953076 & 336538.57 & 2130997 & 441803.18 & 2654358 & 601154.88 \\
\hline 4 & Central Region & 848514 & 83898.12 & 902222 & 95385.11 & 1062759 & 133230.00 \\
\hline 5 & Western Region & 1140601 & 138696.27 & 1097448 & 124694.93 & 1388615 & 205275.15 \\
\hline 6 & Southern Region & 3724598 & 979657.70 & 3649296 & 1215826.80 & 3836418 & 1289928.25 \\
\hline & Total & 8576875 & 1611422.64 & 8744437 & 1959211.52 & 10014243 & 2332448.15 \\
\hline
\end{tabular}

Source: Various NABARD Reports 2016-17.

\section{Review of literature}

Swapanadip Sarkar, Iswar Chandra Malik (2019)1, "Self Help Group in West Bengal - PEST Analysis", The outcome of the study delivers that there is a strong impact of SHGs in the core factor of the societal environment i.e. political, economic social and technological. The Government of India and Government of West Bengal have truly concentrated and nurtured this SHG movement and are taking adequate steps for further improvement. The Government of West Bengal has a keen interest in the development of small, medium and cottage industries (MSME), so many subsidized schemes are initiated for their upliftment. During the study we have also noticed various problems which required strong focus and immediate solution and hence this will extend a path of further research.

Selvi R (2019)2 , Conceptual Framework of Women Self help Groups", the development of a nation depends on the improvement of the rural economy. Poverty and unemployment are the key evils faced by developed countries, to which India is no exemption. In India, most of the people are living in the rural areas below the poverty line. So, providing finance to these people has been considered as an important issue for the Government of India. The financial responsibility is one of the basic needs of the poorer section of the society for socio-economic development. The more attractive scheme with less effort is "Self-Help Group". Women are rendering a major role in the formal economies regulated by society and are continuing to be a large part of the informal economies.

\section{Objectives}

In order to study them the following objectives have been formulated:

1. To portray the profile of voluntary organization under study area.

2. To assess the activities and functioning of self-help groups in terms of operations, activities, strategies, problems and further perspectives.

3. To study the need and the dimension of linkages of self-help groups (SHGs) with banks/financial institutions.
4. To examine the impact of Self-Help Groups (SHGs) in empowerment of rural women in the study area.

5. To suggest the necessary for better measures better performance of the SHGs.

\section{METHODOLOGY}

In order to study the above objectives, one of the Assist voluntary organizations in Prakasam district of Andhra Pradesh has been selected. A multi-stage random sampling procedure has been adopted to select the voluntary organization in the district, the activities that have been undertaken by the selected voluntary organization, the research aims outline the functioning of 60 Self-help Groups (SHGs) out of 1019. The researcher has selected a total sixty self-help groups from four villages based on a simple random sampling method. From each group 5 members were selected by the following same method. The total sample size is 300 .

\section{Tools of Data Collection}

The study was carried out in the Prakasam districts of Andhra Pradesh. Both primary and secondary data has been collected for the study. The primary data has been collected by the sample respondents and to assess the impact of self-help groups such as involvement of voluntary organization, changes in their income and employment aspect have been covered, the secondary data has been obtained from the official records, besides published and unpublished reports. The collected data are analyzed by classifying and tabulating. The percentage tool is used to examine women empowerment through SHGs.

\section{Primary data}

In order to collect primary data, an interview schedule on various aspects of the SHG members is canvassed. The primary data was collected from these 300 sample respondents using a pre-tested questionnaire. The interview schedule is divided into various parts, viz., personal details of the respondent, Socio-economic conditions of the respondents, perception on SHGs and its impact and other relevant information needed for the analysis. 


\section{Sampling}

Regarding sample size considered in this study, the selected sample of 300 is not too small, as the selected Prakasam district of Andhra Pradesh is very backward in socio-economic grounds, followed by the spread of SHG activities are also considerably limited among the women households in the study area. Due to these constraints the researcher has selected a considerable sample of 300 Women SHG members in the study area during the year 2016-17.

\section{Frame work of Data Analysis}

In order to simplify the data, the present research study has incorporated both quantitative and qualitative analysis, however, quantitative analysis was the major technique used for analysis. After collecting the data, it was entered into the computer to analyze through SPSS (Statistical Package for Social Sciences) Software. Descriptive statistical methods were applied to analyze the data. Cross tables are drawn to analyze the data. The frequencies and percentages were calculated to interpret findings. Chi-square test is used to test the significance of the data. A Chi-square test statistic is computed to test whether there is any association between various activities chosen and the reasons behind selecting a particular activity.

\section{DATA ANALYSIS \\ Age of the Respondent}

Age-wise distribution of the respondents has been shown in the table no.2. Most of the respondents i.e., 99 (33.00 per cent) are in between 30 and 35 years of age, 77 are in between 35 and 40 years of age, 74 (24.07 percent) are in 40 years of age and above, 33 (11.00 per cent) are in between 25 and 30 years and 17 (5.07 per cent) are in between 20 and 25 years. On the whole it can be inferred that nearly 80 per cent of the respondents are in the productive agegroup (30-40years). This group of people can withhold courage, innovation, creativity and ability to take risk. There is a need to encourage more number of middle aged as well as above 50 years age group women also to form SHGs in order to achieve the objectives of the SHGs.

Table No.2: Age of the of the respondent

\begin{tabular}{|c|c|c|c|c|c|}
\hline \multirow{2}{*}{$\begin{array}{c}\text { Age of the } \\
\text { Respondent }\end{array}$} & \multicolumn{4}{|c|}{ Community-wise } & \multirow[t]{2}{*}{ Total } \\
\hline & ST & SC & BC & OC & \\
\hline $20-25$ years & $\begin{array}{c}6 \\
(15.00)\end{array}$ & $\begin{array}{c}4 \\
(11.04)\end{array}$ & $\begin{array}{c}2 \\
(1.03)\end{array}$ & $\begin{array}{c}5 \\
(6.08)\end{array}$ & $\begin{array}{c}17 \\
(5.07)\end{array}$ \\
\hline $25-30$ years & $\begin{array}{c}5 \\
(12.05)\end{array}$ & $\begin{array}{c}5 \\
(14.03)\end{array}$ & $\begin{array}{c}17 \\
(11.03)\end{array}$ & $\begin{array}{c}6 \\
(8.01)\end{array}$ & $\begin{array}{c}33 \\
(11.00)\end{array}$ \\
\hline 30-35 years & $\begin{array}{c}11 \\
(27.05) \\
\end{array}$ & $\begin{array}{c}6 \\
(17.01)\end{array}$ & $\begin{array}{c}62 \\
(41.01) \\
\end{array}$ & $\begin{array}{c}20 \\
(27.00) \\
\end{array}$ & $\begin{array}{c}99 \\
(33.00) \\
\end{array}$ \\
\hline $35-40$ years & $\begin{array}{c}7 \\
(17.05)\end{array}$ & $\begin{array}{c}10 \\
(28.06)\end{array}$ & $\begin{array}{c}38 \\
(25.02)\end{array}$ & $\begin{array}{c}22 \\
(29.07)\end{array}$ & $\begin{array}{c}77 \\
(25.07)\end{array}$ \\
\hline 40 and above & $\begin{array}{c}11 \\
(27.05)\end{array}$ & $\begin{array}{c}10 \\
(28.06)\end{array}$ & $\begin{array}{c}32 \\
(21.01)\end{array}$ & $\begin{array}{c}21 \\
(28.04)\end{array}$ & $\begin{array}{c}74 \\
(24.07)\end{array}$ \\
\hline Total & $\begin{array}{c}40 \\
(100.0)\end{array}$ & $\begin{array}{c}35 \\
(100.0)\end{array}$ & $\begin{array}{c}151 \\
(100.0)\end{array}$ & $\begin{array}{c}74 \\
(100.0) \\
(100\end{array}$ & $\begin{array}{c}300 \\
(100.0) \\
\end{array}$ \\
\hline
\end{tabular}

Source: Compiled from collected data.

Note: Figures in the parentheses indicate percentages.

\section{Educational status of the Respondent}

Table no. 3 shows the educational status of the respondents in the selected area. From the total respondents, 130 (43.03 per cent) are just literates whereas secondly, 67 (22.03 per cent) are primary educated, 48 (16.00 per cent) are illiterates, 33 (11.00 per cent) are done with upper primary, 19 (6.03 per cent) are done high school studies and 3 (1.00 per cent) are completed college level. It can be concluded that more than 40 per cent are just literates as they are more in need of micro-finance and women empowerment to carry out small sector units or handicrafts or petty business etc. 
Table No.3: Educational status of the respondent

\begin{tabular}{|l|c|c|c|c|c|}
\hline \multirow{2}{*}{$\begin{array}{c}\text { Educational } \\
\text { Status }\end{array}$} & \multicolumn{4}{|c|}{ Community-wise } & Total \\
\cline { 2 - 5 } & ST & SC & BC & OC & \\
\hline \multirow{2}{*}{ Just literate } & 22 & 11 & 62 & 35 & 130 \\
\hline Primary & $(55.00)$ & $(31.04)$ & $(41.01)$ & $(47.03)$ & $(43.03)$ \\
education & 7 & 14 & 31 & 15 & 67 \\
\hline \multirow{2}{*}{ Upper primary } & $(17.05)$ & $(40.00)$ & $(20.05)$ & $(20.03)$ & $(22.03)$ \\
\hline \multirow{2}{*}{ High School } & 3 & 2 & 24 & 4 & 33 \\
& $(7.05)$ & $(5.07)$ & $(15.09)$ & $(5.04)$ & $(11.00)$ \\
\hline \multirow{2}{*}{ College } & 2 & 7 & 7 & 3 & 19 \\
& $(5.00)$ & $(20.00)$ & $(4.06)$ & $(4.00)$ & $(6.03)$ \\
\hline \multirow{2}{*}{ Illiterates } & 1 & 1 & 1 & 0 & 3 \\
& $(2.05)$ & $(2.09)$ & $(0.07)$ & $(0.00)$ & $(1.00)$ \\
\hline \multicolumn{1}{|c|}{ Total } & 4 & 0 & 26 & 17 & 48 \\
& $(100.05)$ & $(0.00)$ & $(17.02)$ & $(23.00)$ & $(16.00)$ \\
\hline
\end{tabular}

Source: Compiled from collected data.

\section{Note: Figures in the parentheses indicate percentages.}

\section{Awareness on SHGs before Joining}

Table no.4 details the cross sectional analysis between Awareness of the working of SHG before joining as a member and category wise of the respondents. Out of the total sample, 295 (98.03 per cent) respondents got awareness of it and only 5 respondents ( 1.07 per cent) do not have awareness of it.

Table No.4: Awareness of the working of SHGs before joining

\begin{tabular}{|l|c|c|c|c|c|}
\hline \multirow{2}{*}{$\begin{array}{c}\text { Awareness of the working of SHG before } \\
\text { joining }\end{array}$} & \multicolumn{4}{|c|}{ Community-wise } & Total \\
\cline { 2 - 6 } & ST & SC & BC & OC & \\
\hline \multirow{2}{*}{ Aware } & 39 & 35 & 148 & 73 & 295 \\
& $(97.05)$ & $(100.00)$ & $(98.00)$ & $(98.06)$ & $(98.03)$ \\
\hline \multirow{2}{*}{ Not aware } & 1 & 0 & 3 & 1 & 5 \\
& $(2.05)$ & $(0.0)$ & $(2.00)$ & $(1.04)$ & $(1.07)$ \\
\hline \multirow{2}{*}{ Total } & 40 & 35 & 151 & 74 & 300 \\
& $(100.0)$ & $(100.0)$ & $(100.0)$ & $(100.0)$ & $(100.0)$ \\
\hline
\end{tabular}

Source: Compiled from collected data.

Note: Figures in the parentheses indicate percentages.

When it is noticed through community wise, out of total Scheduled Tribe (STs) respondents, 39 (97.05 per cent) have awareness and only 1 respondent (2.05 per cent) do not have awareness. Among Scheduled Castes (SCs), all the respondents have awareness about the voluntary organization. While coming to Backward Class (BCs), 148 (98 per cent) respondents have awareness and only 3 (2 percent) do not have awareness. Among the Other Community (OC), 73 (98.06 per cent) respondents have awareness and only 1 (1.04 per cent) respondents do not have awareness. It is observed that there is good awareness about the organization and programmes among the respondents in the study area.

\section{Mode of Information}

Table no. 5 shows the cross sectional analysis between the mode of information about the SHGs and Community wise of the respondents. Majority of the respondents i.e199 (66.03 percent) have acquired from Non Government Organisation employees, 46 respondents (15.03 percent) from village leaders, 38 respondents (12.07 per cent) from friends or relatives, 13 respondents (4.03 per cent) from leaders or members of SHGs and only 4 respondents from radio or through newspapers.

When coming to the ST community, 35 (87.05 percent) respondents acquired from Non Government Organisation employees, 2 respondents (5.00 per cent) from radio or newspapers and friends or relatives each, and only 1 (2.05 per cent) respondents from leaders or members of SHGs. Among the SCs, 29 (82.09 percent) respondents, 5 (14.03 per cent) respondents and only 1 (2.09 percent) respondents acquired from Non Government Organisation employees, leaders/ members of SHGs and village leaders simultaneously. While in the $\mathrm{BC}$ community, 86 respondents (56.03 per cent) acquired from Non Government Organisation employees, 26 (17.02 per cent) respondents from friends or relatives and only 2 (1.03 per cent) respondents through radios/ 
newspapers and leaders or members of SHGs each. Among the OCs, 50 (67.06 per cent) respondents from Non Government Organisation employees, 10 (13.05 per cent) respondents from friends or relatives, 9 respondents (12.02 per cent) and only 5 (6.08 per cent) respondents from leaders or members of SHGs. Overall, it can be stated that half of the respondents have acquired information from Non Government Organisations. The Pearson Chi-square value is 50.511 at a high significant level.

Table No.5: Mode of information about the SHGs

\begin{tabular}{|c|c|c|c|c|c|c|}
\hline & \multicolumn{4}{|c|}{ Community-wise } & \multirow[t]{2}{*}{ Total } \\
\hline & & ST & SC & BC & OC & \\
\hline \multirow{5}{*}{$\begin{array}{l}\text { Mode of information } \\
\text { about the SHGs }\end{array}$} & Radio/Newspapers & $\begin{array}{r}2 \\
(5.0)\end{array}$ & $\begin{array}{r}0 \\
(0.0)\end{array}$ & $\begin{array}{r}2 \\
(1.3)\end{array}$ & $\begin{array}{r}0 \\
(0.0)\end{array}$ & $\begin{array}{r}4 \\
(1.3)\end{array}$ \\
\hline & Friends/Relatives & $\begin{array}{r}2 \\
(5.00) \\
\end{array}$ & $\begin{array}{r}0 \\
(0.00) \\
\end{array}$ & $\begin{array}{r}26 \\
(17.02) \\
\end{array}$ & $\begin{array}{r}10 \\
(13.05) \\
\end{array}$ & $\begin{array}{r}38 \\
(12.07) \\
\end{array}$ \\
\hline & Village leaders & $\begin{array}{r}0 \\
(0.00)\end{array}$ & $\begin{array}{r}1 \\
(2.09)\end{array}$ & $\begin{array}{r}36 \\
(23.08)\end{array}$ & $\begin{array}{r}9 \\
(12.02)\end{array}$ & $\begin{array}{r}46 \\
(15.03)\end{array}$ \\
\hline & $\begin{array}{l}\text { Non Government Organisation } \\
\text { employees }\end{array}$ & $\begin{array}{r}35 \\
(87.05)\end{array}$ & $\begin{array}{r}29 \\
(82.09)\end{array}$ & $\begin{array}{r}85 \\
(56.03)\end{array}$ & $\begin{array}{r}50 \\
(67.06)\end{array}$ & $\begin{array}{r}199 \\
(66.03)\end{array}$ \\
\hline & Leader/member of SHG & $\begin{array}{r}1 \\
(2.05)\end{array}$ & $\begin{array}{r}5 \\
(14.03)\end{array}$ & $\begin{array}{r}2 \\
(1.03)\end{array}$ & $\begin{array}{r}5 \\
(6.08)\end{array}$ & $\begin{array}{r}13 \\
(4.03)\end{array}$ \\
\hline \multicolumn{2}{|l|}{ Total } & $\begin{array}{r}40 \\
(100.0)\end{array}$ & $\begin{array}{r}35 \\
(100.0)\end{array}$ & $\begin{array}{r}151 \\
(100.0)\end{array}$ & $\begin{array}{r}74 \\
(100.0)\end{array}$ & $\begin{array}{r}300 \\
(100.0)\end{array}$ \\
\hline
\end{tabular}

Source: Compiled from collected data.

Note: Figures in the parentheses indicate percentages.

${ }^{*} \chi^{2}=50.511, \mathrm{df}=12$, Significant at 0.000 level.

\section{Preference to Join in SHGs}

Table no.6 describes the cross sectional analysis between the preference of SHGs to join by the respondents and community of respondents. Out of 300, 265 (88.03 per cent) preferred to join Non Government Organisation organized SHGs and remaining 35 (11.07 per cent) prefer Government / DRDA organized SHGs.

After going through the above strata, there is a community wise differentiation. Maximum number of the sample preferred Non Government Organisation organized SHGs with 26 (65.00 per cent) in STs, 30 (85.07 percent) in SCs, 143 (94.07 per cent) in BCs and 66 (89.02 per cent) in OCs. While on the other hand, remaining sample is preferred to Government/DRDA organized SHGs with 14 (35.00 per cent) in STs, 5 (14.03 per cent) in SCs, 8 (5.03 per cent) are in BCs and only 8 (10.08 per cent) are in Other Community.

Table No.6 : Preference to join SHGs

\begin{tabular}{|l|l|r|r|r|r|r|}
\hline \multicolumn{2}{|c|}{} & \multicolumn{3}{c|}{ Community-wise } & \multicolumn{1}{c|}{ Total } \\
\cline { 2 - 6 } \multicolumn{3}{|c|}{ Preference of SHGs } & \multicolumn{1}{c|}{ ST } & SC & \multicolumn{1}{c|}{ BC } & \\
\hline & Non Government Organisation & 26 & 30 & 143 & 66 & 265 \\
\cline { 2 - 6 } & organized SHGs & $(65.00)$ & $(85.07)$ & $(94.07)$ & $(89.02)$ & $(88.03)$ \\
\cline { 2 - 6 } & Government / DRDA organized & 14 & 5 & 8 & 8 & 35 \\
& SHGs & $(35.00)$ & $(14.03)$ & $(5.03)$ & $(10.08)$ & $(11.07)$ \\
\hline \multirow{2}{*}{ Total } & 40 & 35 & 151 & 74 & 300 \\
\end{tabular}

Source: Compiled from collected data.

Note: Figures in the parentheses indicate percentages. $* \chi^{2}=27.361, \mathrm{df}=3$, Significant at 0.000 level.

From the above table, it is depicted that more than 88 per cent of the whole sample preferring Non Government Organisation organized SHGs. The Pearson Chi-square value is 27.361 at a high significant level.

\section{Support Received}

The respondents received support while forming SHGs in the village by the respondents in the table no.V.7. 276 (92 per cent) received support from Non Government Organisation /NGO officials,
12 (4.00 percent) received from village leaders, 8 ( 2.07 per cent) received from bank officials and 4 (1.03 percent) received from DRDA staff. As part of it, all the community respondents received maximum assistance from Non Government Organisation / Non Government Organisation officials. In the Scheduled Tribe, 34 (85.00 per cent) received from Non Government Organisation /NGO officials and 6 (15.00 percent) are bank officials. 
Table No. 7 : Support received in the formation of SHGs

\begin{tabular}{|c|c|c|c|c|c|c|}
\hline & \multicolumn{4}{|c|}{ Community-wise } & \multirow[t]{2}{*}{ Total } \\
\hline & & ST & SC & BC & OC & \\
\hline \multirow{4}{*}{$\begin{array}{l}\text { Support received in the } \\
\text { formation of SHGs }\end{array}$} & DRDA Staff & $\begin{array}{r}0 \\
(0.00)\end{array}$ & $\begin{array}{r}0 \\
(0.00) \\
\end{array}$ & $\begin{array}{r}2 \\
(1.03) \\
\end{array}$ & $\begin{array}{r}2 \\
(2.07) \\
\end{array}$ & $\begin{array}{r}4 \\
(1.03)\end{array}$ \\
\hline & Bank officials & $\begin{array}{r}6 \\
(15.00)\end{array}$ & $\begin{array}{r}1 \\
(2.09)\end{array}$ & $\begin{array}{r}1 \\
(0.07)\end{array}$ & $\begin{array}{r}0 \\
(0.00)\end{array}$ & $\begin{array}{r}8 \\
(2.07)\end{array}$ \\
\hline & Village Leaders & $\begin{array}{r}0 \\
(0.00) \\
\end{array}$ & $\begin{array}{r}6 \\
(17.01) \\
\end{array}$ & $\begin{array}{r}2 \\
(1.03) \\
\end{array}$ & $\begin{array}{r}4 \\
(5.04) \\
\end{array}$ & $\begin{array}{r}12 \\
(4.00) \\
\end{array}$ \\
\hline & $\begin{array}{l}\text { Non Government } \\
\text { Organisation / } \\
\text { officials }\end{array}$ & $\begin{array}{r}34 \\
(85.00)\end{array}$ & $\begin{array}{r}28 \\
(80.00)\end{array}$ & $\begin{array}{r}146 \\
(96.07)\end{array}$ & $\begin{array}{r}68 \\
(91.09)\end{array}$ & $\begin{array}{r}276 \\
(92.00)\end{array}$ \\
\hline \multicolumn{2}{|l|}{ Total } & $\begin{array}{r}40 \\
(100.0)\end{array}$ & $\begin{array}{r}35 \\
(100.0)\end{array}$ & $\begin{array}{r}151 \\
(100.0)\end{array}$ & $\begin{array}{r}74 \\
(100.0)\end{array}$ & $\begin{array}{r}300 \\
(100.0)\end{array}$ \\
\hline
\end{tabular}

Source: Compiled from collected data.

Note: Figures in the parentheses indicate percentages.

$* \chi^{2}=\mathbf{5 0 . 0 1 4}, \mathrm{df}=9$, Significant at 0.000 level.

In the Scheduled Caste, 28 (80 percent) are Non Government Organisation / NGO officials, 6 (17.01 per cent) are village leaders and 1 (2.09 percent) are bank officials. When it comes to Backward Community, 146 (96.07 per cent) are Non Government Organisation /NGO officials, 2 (1.03 per cent) are DRDA staff and bank officials. At last, 68 (91.09 per cent) are Non Government Organisation /NGO officials, 4 (5.04 per cent) are village leaders and 2 (2.07 per cent) are DRDA staff in Other Community. The Pearson Chi-square value is 50.014 at a highly significant level.

\section{Financial support}

Table no.V.8 shows the various financial supporters for the training of respondents and community wise. Out of the total respondents 300, 254 (84.07 percent) got support from Non Government Organisation s and rest of them i.e. 28 (9.03 per cent), 16 (5.03 per cent) and 2 (0.07 per cent) do not attend training, SHGs and training institutions.

Among various community wise respondents, in the Scheduled Tribe, 32 (80.00 percent) got support from Non Government Organisation s, 6 (15.00 percent) from SHGs and 2 (5.00 percent) do not attend training. In the Scheduled Caste, 30 (85.07 percent) got support from Non Government Organisations and 2 (5.00 percent) do not attend training.

Table No.8 : Financial supporters for the trainings of respondents

\begin{tabular}{|c|c|c|c|c|c|c|}
\hline & \multicolumn{4}{|c|}{ Community-wise } & \multirow[t]{2}{*}{ Total } \\
\hline & & ST & SC & BC & OC & \\
\hline \multirow{4}{*}{ Financial Supporters } & SGHs & $\begin{array}{r}6 \\
(15.00)\end{array}$ & $\begin{array}{r}0 \\
(0.00)\end{array}$ & $\begin{array}{r}6 \\
(4.00)\end{array}$ & $\begin{array}{r}4 \\
(5.04)\end{array}$ & $\begin{array}{r}16 \\
(5.03)\end{array}$ \\
\hline & Training Institution & $\begin{array}{r}0 \\
(0.00)\end{array}$ & $\begin{array}{r}0 \\
(0.00)\end{array}$ & $\begin{array}{r}2 \\
(1.03)\end{array}$ & $\begin{array}{r}0 \\
(0.00)\end{array}$ & $\begin{array}{r}2 \\
(0.07)\end{array}$ \\
\hline & $\begin{array}{l}\text { Non Government } \\
\text { Organisation s }\end{array}$ & $\begin{array}{r}32 \\
(80.00)\end{array}$ & $\begin{array}{r}30 \\
(85.07)\end{array}$ & $\begin{array}{r}127 \\
(84.01)\end{array}$ & $\begin{array}{r}65 \\
(87.08)\end{array}$ & $\begin{array}{r}254 \\
(84.07)\end{array}$ \\
\hline & Not applicable & $\begin{array}{r}2 \\
(5.00)\end{array}$ & $\begin{array}{r}5 \\
(14.03)\end{array}$ & $\begin{array}{r}16 \\
(10.06)\end{array}$ & $\begin{array}{r}5 \\
(6.08)\end{array}$ & $\begin{array}{r}28 \\
(9.03)\end{array}$ \\
\hline \multicolumn{2}{|l|}{ Total } & $\begin{array}{r}40 \\
(100.0)\end{array}$ & $\begin{array}{r}35 \\
(100.0)\end{array}$ & $\begin{array}{r}151 \\
(100.0)\end{array}$ & $\begin{array}{r}74 \\
(100.0)\end{array}$ & $\begin{array}{r}300 \\
(100.0)\end{array}$ \\
\hline
\end{tabular}

Source: Compiled from collected data.

Note: Figures in the parentheses indicate percentages. $* \chi^{2}=14.082, \mathrm{df}=9$, Significant at 0.119 level.

In Backward Community, 127 (84.01 percent) got support from Non Government Organisation $\mathrm{s}$ and rest of them i.e. 16 (10.06 per cent), 6 (4.00 per cent) and 2 (1.03 per cent) do not attend training, SHGs and training institutions. As of Other
Community, 65 (87.08 per cent), 5 (6.08 per cent), 4 (5.04 per cent) got support from Non Government Organizations, do not attend training and SHGs. From the above statistics, it is clear that maximum of the respondents got financial support from the Non 
Government Organizations. The Pearson Chi-square value is 14.082 at 0.119 significant level.

\section{Support obtained to avail loan}

Table no.9 describes the support obtained by the respondents in availing loans and the community wise of the respondents. Out of 300 , maximum of the respondents i.e. 232 (77.03 percent) obtained Non Government Organization official support, 56 (18.07 percent) received friends/ relatives support and only 12 (4 percent) obtained bank officials support.
In the distribution of data through community wise, in the Scheduled Tribe, 28 (70 percent) obtained Non Government Organization official support, 569 (22.05 per cent) received friends/ relatives support and only 3 (7.05 per cent) obtained bank officials support. In the Scheduled Caste, all the members have NOG officials support while getting loans. Whereas in Backward Community, 114 (75.05 percent) have obtained Non Government Organization officials support, 29 (19.02 per cent) have obtained friends/ relatives support and only 8 (5.03 per cent) have bank officials assistance.

Table No.9 : Support obtained by the respondents to availing loans

\begin{tabular}{|c|c|c|c|c|c|c|}
\hline & \multicolumn{4}{|c|}{ Community-wise } & \multirow[t]{2}{*}{ Total } \\
\hline & & ST & SC & BC & OC & \\
\hline \multirow{3}{*}{$\begin{array}{l}\text { Support } \\
\text { obtained }\end{array}$} & Officials of the bank & $\begin{array}{r}3 \\
(7.5) \\
\end{array}$ & 0 & $\begin{array}{r}8 \\
(5.3) \\
\end{array}$ & $\begin{array}{r}1 \\
(1.4)\end{array}$ & $\begin{array}{r}12 \\
(4.0) \\
\end{array}$ \\
\hline & $\begin{array}{l}\text { Non Government } \\
\text { Organisation officials }\end{array}$ & $\begin{array}{r}28 \\
(70.00) \\
\end{array}$ & $\begin{array}{r}35 \\
(100.00) \\
\end{array}$ & $\begin{array}{r}114 \\
(75.05) \\
\end{array}$ & $\begin{array}{r}55 \\
(74.03) \\
\end{array}$ & $\begin{array}{r}232 \\
(77.03) \\
\end{array}$ \\
\hline & Friends/Relatives & $\begin{array}{r}9 \\
(22.05)\end{array}$ & 0 & $\begin{array}{r}29 \\
(19.02) \\
\end{array}$ & $\begin{array}{r}18 \\
(24.03)\end{array}$ & $\begin{array}{r}56 \\
(18.07) \\
\end{array}$ \\
\hline \multicolumn{2}{|l|}{ Total } & $\begin{array}{r}40 \\
(100.0) \\
\end{array}$ & $\begin{array}{r}35 \\
(100.0) \\
\end{array}$ & $\begin{array}{r}151 \\
(100.0) \\
\end{array}$ & $\begin{array}{r}74 \\
(100.0) \\
\end{array}$ & $\begin{array}{r}300 \\
(100.0) \\
\end{array}$ \\
\hline
\end{tabular}

Source: Compiled from collected data.

Note: Figures in the parentheses indicate percentages. $* \chi^{2}=15.455, \mathrm{df}=6$, Significant at 0.017 level.

Lastly, in Other Community, 55 (74.03 per cent) obtained Non Government Organisation official support, 18 (24.03 per cent) received friends/ relatives support and only 1 (1.04 per cent) obtained bank officials support. Finally, it is examined that more than 70 per cent of the respondents have been assisted by Non Government Organisation officials. The Pearson Chi-square value is 15.455 at 0.017 significant level.

\section{Observations}

After due consideration of the analysis made earlier the study arrives at the following major findings.

$>$ The study states that nearly 80 per cent of the respondents are in the productive age group, between (30-40years) and they are in more need of micro finance and women empowerment to carry out small sector units, handicrafts or ancillary industries as maximum number of respondents are mere literates.

$>$ The study also found that the majority of the respondents have acquired information regarding SHGs from local Non Government Organizations and also those employees are involved in encouraging the respondents to join SHGs.

$>$ There is a good awareness and motivation to join in SHGs about the organization and programmes among the respondents through Non Government Organization employees.
It is assumed that nearly 90 per cent had a good awareness about the SHGs and they preferred to join Non Government Organization organized SHGs. The reason being organization has to improve economic conditions.

$>$ Non Government Organization/ NGO officials have been supported during the formation of SHGs. A huge part of the respondents attends the meeting regularly to know the loan details. Being part of SHG, maximum numbers of respondents are attending meetings or training at NGO offices.

$>$ Most likely, meetings conducted by NGO officials last up to one to three days. They receive financial assistance from Non Government Organizations.

$>$ Through these SHGs, most of them are getting awareness on Government programs. Through these, they have improved economically which has made them skillful. Members acquired group management skills and technical skills through training from Non Government Organizations.

$>$ Majority of them do not face market facilities problems, they get support in availing loans through Non Government Organizations and few of them lack market knowledge. 


\section{Suggestions}

Based on the above findings, the following are the various suggestions to improve the socioeconomic conditions of the sample respondents.

$>$ Majority of the SHG members are using loans for unproductive purposes which leads them to indebtedness. So there is a need to educate the members on usage of loans for productive purposes, in order to improve and empower the economic conditions and empower of the women in India.

$>$ The ability of women to demand their rights such as fair wages and decent working conditions is often undermined due to their unfavourable position in the labour markets as well as a lack of a forum that can represent their collective grievances.

$>$ The present methodology training, which is being given to SHGs members, needs to be changed by increasing the duration of training period and result oriented. A competent team of trainers consisting of Non Government Organizations and animators should be entrusted with the task.

$>$ The SHGs are majorly dependent upon the Non Government Organizations in the financial decision making process. Hence, the government should encourage more Non Government Organizations for involvement in the SHGs activities.

$>$ Skill development programmes should be launched especially for rural women.

$>$ The sample SHGs faced the problem of inadequate loan amounts. Loan is one of the basic components to start an activity and also women can be financially sound when the loan amount provided meets their needs. Loan amount should be increased to the extent that they can take up an income generating activity.

$>$ It is suggested that incentives may be given for prompt repayment. This will catch the attention of the groups for timely repayment of the loan. Further, suitable advice may also be given to the members of SHGs in ways for timely repayment of loan.

$>$ It is also suggested that the governmental and non-governmental institutions should be engaged as facilitators in the process of selfhelp group formation so to have at test one Self Help Groups in every village.

\section{CONCLUSION}

In conclusion, the majority of the sample respondents of the present study belongs to BCs and young in age groups in the study area. More than 90 per cent women respondents are married who are in need of microfinance to support their families economically through running various small sector units or businesses. The present study can be inferred that nearly 80 per cent of the respondents are in the productive age-group of between (30-40years). This group of people can withhold courage, innovation, creativity and ability to take risk. There is a need to encourage more number of middle aged as well as above 50 years age group women also to form SHGs in order to achieve the objectives of the SHGs.

\section{REFERENCES}

1. Meenakshi Malhotra (2004), "Empowerment of Women”, New Delhi: Isha Books, p.p.54-55.

2. Peter J.Mc Cann,(2006) A review of the Anonymous Self-Help Groups and Their utilization in professional settings, 2006,pp.1-9.

3. Jayaraman, R. (2008). Performance Analysis of Fisher women Self-Help Groups, Tamilnadu Journal of Veterinary and Animal Sciences, 4(2), March-April, 52-55.

4. Suguna B (2009), “Women's Empowerment: Dimensions and Directions", Report of Social Welfare, pp.5-9.

5. Jayasheela, Shriprasad H, Denesta P.T (2009), "The concept of Microfinance and its Significance", Microfinance in India a tool for women Empowerment, Serials Publications, New Delhi-110002, p.p.58-79.

6. Ramakrishna, H, et al (2013), "Performance of Self-Help Group-Bank Linkage Performance $(S B L P)$ in India: An Analytical Study”, Tactful Management Research Journal, Vol.1, No.10, July, pp.1-6.

7. Javaid Ahmad Mir (2018), "Sustainability Of SHG Federations Formed Under NRLM(UMEED)", International Journal of Humanities and Social Science Invention (IJHSSI), Vol.7, Issue 05, Ver. II, pp.08-12.

8. Report of NABARD, 2018-19.

9. Swapanadip Sarkar, Iswar Chandra Malik (2019), "Self Help Group in West Bengal - PEST Analysis", IOSR Journal Of Humanities And Social Science (IOSR-JHSS), Vol.24, Issue 8, Ser. 5 (August. 2019), pp.42-50.

10. Dr.R.Selvi (2019), "Conceptual Framework of Women Self help Groups", IJRAR, September, Vol.6, Issue 3, pp.110-113

11. Nimisha. M, Dharmaraj Arumugam (2019), "Impact of Self-Help Groups on Self, Social Awareness and Economic Empowerment of Women Entrepreneurs of Coimbatore District", International Journal of Engineering and Advanced Technology (IJEAT), Vol.8, Issue-5, June.

12. Kishore Prabhala and Umamaheswara Rao $T$ (2019), "A review on digitalization of SHG with mobile usage in India", International Journal of Advance Research, Ideas and Innovations in Technology, Vol.5, Issue No.3, pp.1798-1802. 